\title{
PENGARUH MORAL KOGNITIF PADA KINERJA KEPERILAKUAN DAN KINERJA HASIL TENAGA PENJUALAN
}

\author{
Ribhan (ribhan_ashari@yahoo.com; ribhan@unila.ac.id) \\ Nasrullah Yusuf (nasrullah@unila.ac.id)
}

Fakultas Ekonomi dan Bisnis Universitas Lampung

\begin{abstract}
Ethical decision making has become a critical issue as the pressure to improve the behavior of successful salespeople in all the current economic conditions. The values contained in the employees will affect the decision making of individuals or employees that will have an impact on organizational performance. Moral or cognitive moral is at the core of the most ethical decision-making models in the marketing and management. This study examined the effect of cognitive moral behavioral performance and outcome performance of the sales force and influence behavioral performance in sales force outcome performance. By using simple linear regression method obtained results that the hypothesis that cognitive moral effect on behavioral performance of salespeople, singnifikan effect ( $b=-0.296$; sig 0.000) supported. Hypothesis 2 is not supported, which suggests that moral considerations affect the outcome performance in this study were not significant $(b=-0.122$; sig .148). The next hypothesis states that behavioral performance positive influence on the outcome performance of the support ( $b=0.217$; sig 0.009 ). To obtain the results of an individual's performance is good and responsible, it must enhance or improve the behavior of decisionmaking is based on cognitive moral salespeople. Performance results of the sales force increased when the behavior of salespeople work better and responsible.
\end{abstract}

Keywords: moral cognitive, behavioral performance, outcome performance

\section{PENDAHULUAN}

Pengambilan keputusan etis telah menjadi suatu isu kritis sebagai tekanan untuk meningkatkan perilaku keberhasilan tenaga penjual (Valentine, 2009) dalam semua kondisi ekonomi saat ini. Pertimbangan moral sebagai sebuah acuan untuk berperilaku etis dan pengambilan keputusan benar dan salah akan berperan dalam pengambilan keputusan etis pemasar (Ferrell dan Gresham, 1985). Sehingga konsumen akan semakin mempertimbangkan reputasi etika perusahaan ketika mereka membuat keputusan pembelian. Beberapa organisasi penjualan sudah beralih ke pertimbangan etika sebagai titik kunci penjualan (Gilbert, 2003).

Tenaga penjual adalah wajah organisasi untuk orang-orang dengan siapa mereka berkomunikasi. Akibatnya, perilaku penjual adalah instrumental dalam menentukan reputasi perusahaan antara pembeli dan organiosasi lain. Perilaku etis dapat membantu organisasi penjualan dalam membangun, memelihara dan memperluas hubungan pelanggan bahkan dalam industri.

Nilai-nilai yang ada dalam diri karyawan akan mempengaruhi dalam pengambilan keputusan individu atau karyawan sehingga akan berdampak pada kinerja organisasi. Nilai etika dan etika perilaku dalam beberapa penelitian terakhir menjadi perhatian dari para peneliti dalam rangka pembuatan keputusan etis dan etika perilaku (Wimbush, 1999). Pembuatan keputusan etis yang dikembangkan secara moral kognitif memiliki pengaruh pada kinerja organisasi (Schwepker dan Good, 2011). 


\section{Ribhan Nasrullah Yusuf}

Pengembangan moral kognitif dikembangkan secara konseptual dan diuji secara empiris oleh Lawrence Kohlberg (1984 dalam Schwepker dan Good, 2011) sebagai cara untuk menggambarkan dan menjelaskan proses pembuatan keputusan etis dan etika individu. Dalam bidang pemasaran, proses pembuatan keputusan etis diarahkan untuk meningkatkan kinerja individu dalam menciptakan kepuasan pelanggan eksternal (konsumen).

Kritikan tentang perilaku tidak etis dalam bisnis yang ditujukan pada aktivitas pemasaran semakin banyak. Seperti dikemukakan oleh Murphy dan Laczniak (1981 dalam Goolsby dan Hunt, 1992), pemasaran merupakan area fungsional dalam usaha yang sering kali melakukan pelanggaran etika, baik etika pemasaran ataupun etika pemasar. Miles (1980; dalam Goolsby dan Hunt, 1992 ) menyatakan bahwa karakteristik unik pemasaran, khususnya peran pemasaran yang makin luas dan komplek, adalah kondusif bagi perilaku tidak etis. Dengan demikian, persoalan etika muncul dari fakta bahwa pemasaran pada dasarnya melibatkan penyatuan kebutuhan dari publik yang beragam. Pendapat lain menyatakan bahwa tindakan praktisi pemasaran, jauh lebih terlihat oleh orang-orang di luar organisasi (konsumen eksternal) dibandingkan dengan tindakan di bidang lain dan, sehingga lebih rentan terhadap kritik (Ferrell dan Gresham 1985). Cox, Goodman, dan Finchlande (1965, dalam Goolsby dan Hunt, 1992) menunjukkan sejauhmana masyarakat memandang praktisi pemasaran sebagai "sekadar pedagang keliling", "penipu" dan "curang." Penelitianpenelitian tersebut menunjukkan bahwa bidang pemasaran mungkin akan menarik bagi orang-orang yang rendah dalam hal pengembangan moral kognitif. Namun demikian pemikiran Kohlberg (1969) mengatakan bahwa pemasaran merupakan lingkungan yang "kompleks secara moral" dan akan meningkatkan pengembangan moral kognitif para profesional pemasaran.

Penilaian moral merupakan inti yang paling etis dalam model pengambilan keputusan dalam bidang pemasaran dan manajemen. Sebagian besar penelitian menguji pertimbangan moral (yaitu keputusan untuk berperilaku benar atau salah), nilai-nilai moral (yaitu, keyakinan individu tentang nilai dan tindakan yang benar atau salah), pengembangan kognitif moral (yaitu, pengembangan penalaran moral), ketika moral individu menilai orang lain.

Rest (1986) dan Trevino (1986) menyatakan bahwa moral kognitif adalah elemen penting dalam tahap penilaian keputusan keputusan yang etis. Model pengembangan moral kognitif mengemukakan bahwa individu dapat mempunyai respon yang berbeda dalam dilema etika yang sama karena mereka berada pada tingkat yang berbeda dalam pengembangan kognitif moral mereka (Kohlberg, 1969). Untuk itu maka penilaian aspek moral merupakan inti yang paling etis dalam model pengambilan keputusan dalam bidang pemasaran termasuk tenaga penjual sebagai salah satu faktor penting dalam kinerja individu untuk membangun hubungan relasional dengan konsumen eksternal.

Beberapa peneliti misalnya (Austin dan Villanova, 1992; Motowidlo, 2003; Wall et al., 2004; Gomez-Mejia et al., 2007; Varela dan Landis, 2010) menggunakan variabel kinerja sebagai konstruk yang multidimensional. Sebuah kategorisasi alternatif yang memperkenalkan kemampuan dimensi dasar (dimensi hasil dan dimensi perilaku). Dimensi-dimensi tersebut menunjukkan kemampuan yang dapat diklasifikasikan menurut hasil kerja dan perilaku kerja dalam hal penyampaian, pengerjaan dan pengendalian tingkat keterlibatan dalam interaksi kerja.

Sebagian besar penelitian tentang moral kognitif dalam organisasi berfokus pada identifikasi pengaruh perkembangan moral kognitif karyawan pada perilaku dan sikap (Ferrell dan Gresham, 1985; Hunt dan Vitell, 1986). Namun, sedikit yang diketahui tentang bagaimana moral kognitif mempengaruhi kinerja keperilakuan serta kinerja hasil tenaga penjualan. Penelitian ini menguji pengaruh moral kognitif pada kinerja keprilakukan dan kinerja hasil tenaga penjualan. Penelitian ini juga menguji pengaruh kinerja keperilakuan pada kinerja hasil tenaga penjualan. 


\section{LANDASAN TEORI DAN PENGEMBANGAN HIPOTESIS}

\section{Moral Kognitif}

Moral kognitif dikembangkan secara konseptual dan diuji secara empiris oleh Kohlberg (1969 dalam Goolsby dan Hunt, 1992) sebagai cara untuk menjelaskan proses pembuatan keputusan etis dan etika individu. Kohlberg berpendapat bahwa individu secara berurutan melalui tiga tingkat perkembangan moral dalam pengambilan keputusan yaitu prekonvensional, konvensional, dan post-konvensional, sebelum mencapai kematangan moral. Penelitian Kohlberg banyak mendapat dukungan dengan ditemukannya model untuk pengembangan moral kognitif (Trevino, 1986; Trevino et al., 1998).

Tingkat pre-konvensional pengembangan moral kognitif ditandai dengan keputusan individu berdasarkan pada keprihatinan eksklusif individu untuk dirinya sendiri atau kepentingan pribadi tanpa memperhatikan dampak dari tindakannya pada orang lain. Pada tingkat ini, individu sering bertindak dalam rangka menghindari hukuman. Bahkan ketika individu tertarik pada kesejahteraan lainnya, motif ini untuk mencapai kepentingan pribadi jangka panjang. Pada tingkat ini mereka bereaksi terhadap masalah etis dari sudut pandang egois, mengevaluasi pilihan moral terutama dalam hal konsekuensi pribadi, kebutuhan, dan pertukaran keuntungan.

Pada tingkat konvensional, individu mengakui pentingnya perhatian dan menghormati orang lain yang mempengaruhi dalam keputusan etis. Aturan, prosedur, dan hukuman berfungsi sebagai dasar untuk memahami parameter kesesuaian perilaku. Individu mengidentifikasi benar dan salah tindakan meraka dalam hal hubungan sosial. Lingkungan sosial individu (seperti, teman sebaya, keluarga, masyarakat) dapat mendorong pilihan moral mereka. Perilaku yang benar didefinisikan oleh harapan dan dapat membantu orang lain. Perilaku yang benar ditentukan oleh undang-undang, peraturan, dan kewajiban yang dibutuhkan untuk menjaga ketertiban sosial.

Terakhir, pada tingkat post-konvensional, individu menyadari akan nilai-nilai dan hak-hak yang mendasarinya sebelum pengambilan keputusan. Individu menentukan perilaku yang tepat berdasarkan tugas. Pada tingkat ini, individu mempertimbangkan kemungkinan untuk mengubah hukum, aturan dan prosedur yang berguna untuk tujuan sosial. Pada tahap ini pengembangan moral individu dipandu oleh prinsip-prinsip etis yang dipilih sendiri berdasarkan keadilan, dan hak-hak manusia. Prinsip ini konsisten dengan harapan masyarakat.

Setiap individu dapat mempunyai respon yang berbeda meskipun dihadapkan pada dilema etika yang sama karena mereka berada pada tingkat pengembangan moral kognitif yang berbeda Kohlberg (1969 dalam Trevino, 1986). Sebagai tenaga penjual yang bergerak ke arah pelaksanaan strategi yang dirancang untuk mendorong dan saling mendukung hubungan jangka panjang dengan pelanggan (Weber, 1992), mereka dituntut untuk memulai, menetapkan, dan memelihara hubungan yang abadi. Sebuah pengembangan hubungan jangka panjang menunjukkan pentingnya penempatan perilaku etis (perilaku yang bermoral) yang tinggi. Menurut Gundlach dan Murphy (1993), etika dapat memberikan arahan pada perubahan perilaku dalam mempertahankan hubungan yang lebih fleksibel. Kekhawatiran tentang perilaku etis telah menyebabkan pengembangan berbagai model dan kerangka untuk menganalisis pengambilan keputusan etis pemasaran (Dubinsky dan Loken, 1989; Ferrell dan Gresham, 1985; Ferrell et al., 1989; Hunt dan Vitell, 1986; Wotruba, 1990). Keputusan etis pemasaran juga merupakan aspek moral individu (Bommer et al., 1987; Jones, 1991; Trevino, 1986). Hal ini didukung dengan beberapa penelitian seperti Schwepker (1999) yang mengemukakan bahwa aspek moral mempengaruhi tenaga penjualan untuk berperilaku tidak etis. 


\section{Ribhan Nasrullah Yusuf}

Tenaga penjualan yang bersikap etis lebih efektif untuk membangun hubungan pelanggan yang kuat seperti pelanggan yang puas, percaya dan loyal (Lagace et al., 1991; Roman dan Ruiz, 2005). Perilaku etis yang dihasilkan dari pertimbangan moral akan mengarah pada peningkatan kinerja penjualan dan dapat membantu dalam membangun hubungan jangka panjang dengan pelanggan. Sebuah cara yang berguna untuk menilai kinerja penjualan adalah dengan melihat hasil penjualan dan perilaku tenaga penjual (Anderson dan Oliver, 1987). Perspektif kinerja didasarkan pada hasil objektif (misalnya, penjualan produk, pangsa pasar, keuntungan, pelanggan baru), sedangkan perspektif yang berdasarkan perilaku sering melibatkan penilaian kompleks dan subjektif perilaku wiraniaga (misalnya, etika atau perilaku moral, manajemen waktu, kemampuan komunikasi, inisiatif, dan agresivitas).

\section{Kinerja Tenaga Penjualan}

Dalam beberapa studi, kinerja individual telah menjadi salah satu indikator penting dalam mengukur kinerja organisasi (Wall et al., 2004). Kinerja organisasi seringkali ditentukan oleh angka-angka keuangan, namun dapat juga diukur melalui harapan perilaku dan yang berhubungan dengan aspek tugas (Motowidlo, 2003). Kinerja individu yang didasarkan pada penilaian absolut atau penilaian relatif dapat mencerminkan kinerja organisasi secara keseluruhan (Gomez-Mejia et al., 2007 ; Wall et al., 2004).

Varela dan Landis (2010) memberikan dukungan dengan menyedarhanakan model kinerja berdasarkan skala multidimensi. Mereka menyarankan sebuah kategorisasi alternatif yang memperkenalkan tiga kemampuan dimensi dasar (target perilaku, tingkat pengaruh perilaku dan tingkat keterlibatan). Dimensi-dimensi tersebut menunjukkan kemampuan yang dapat diklasifikasikan menurut target perilaku kerja; tingkat pengaruh perilaku dalam hal penyampaian, pengedalian dan mengerjakan; tingkat keterlibatan dalam interaksi kerja.

Peneliti lain, yaitu Heneman dan Judge (2005) mengemukakan bahwa analisis pekerjaan juga dapat digunakan dalam mengembangkan standar kinerja yang diperlukan dari masing-masing pekerjaan. Analisis pekerjaan menentukan perilaku kerja dan pengetahuan, keterampilan, kemampuan, dan karakteristik lainnya yang diharuskan dari pekerjaan tetap yang paling penting, Wiedower (2001) dan Pincus (1986) menegaskan bahwa mengukur kinerja yang didasarkan pada item penilaian kinerja menawarkan keandalan yang lebih tinggi dalam mengevaluasi kinerja. Schmitt et al. (2003) mengemukakan bahwa kinerja pekerjaan yang mengacu kepada pengetahuan, keahlian dan kemampuan individu akan dibutuhkan dalam melaksanakan pekerjaan tertentu dan akhirnya menunjukkan tingkat motivasi bahwa individu mungkin dalam melakukan pekerjaan mereka. Model dan koseptualisasi kinerja tersebut mendorong para peniliti untuk terus meneliti konsep-konsep kinerja yang dihubungkan dengan variabel atau konstruk lain.

Motowidlo dan Scotter (1994) dan Goolsby dan Hunt (1992) mengukur kinerja yang terdiri dari kinerja tugas dan kinerja kontekstual. Kedua konstruk dipengaruhi oleh faktor-faktor yang berbeda, misalnya yang berhubungan dengan pengalaman kerja, penentuan tugas kinerja dan tipe kepribadian individu yang dapat menentukan kinerja kontekstual. Hal tersebut juga didukung oleh beberapa peneliti seperti Jaworski dan Kohli (1991) yang mengemukakan bahwa efek umpan balik positif (output dan perilaku) tentang kinerja tenaga penjualan mempunyai pengaruh langsung dan tidak langsung melalui kejelasan peran. Sejalan dengan temuan Park and Deitz (2006) bahwa kinerja mempunyai hubungan yang positif signifikan dengan perilaku adaptive menjual pada tenaga penjual. Schwepker and Good (2011) juga mendukung temuan Jaworski dan Kohli, dengan berpendapat bahwa perilaku dan output kinerja berhubungan dengan pertimbangan moral tenaga penjualan.

Para peneliti akhir-akhir ini mulai melakukan penelitian tentang kinerja pekerjaan dengan melibatkan moral kognitif tenaga penjualan seperti kebutuhan kognitif dan orentasi afektif, etika dan moral (Sojka dan Schmelz, 2008; Selvarajan dan Cloninger, 2009; Schwepker dan Good, 2011). Sojka dan Schmelz (2008) menunjukkan baik kebutuhan kognitif dan orientasi efektif berkorelasi dengan perilaku kinerja tenaga penjual, namun hanya kebutuhan kognitif 
yang lebih berpengaruh pada dua kinerja organisasi yaitu perilaku menjual dan hasil penjualan. Temuan ini mendukung penelitian kemampuan kognitif (Oakes et al., 2001) dan ciri-ciri kepribadian ( Riggio dan Taylor, 2000; Jenkins dan Griffitth , 2004) individu dapat memprediksi kinerja karyawan. Selvarajan dan Cloninger (2009) penelitian yang dilakukan pada tenaga penjualan dengan metode eksperimen menyimpulkan bahwa karyawan (tenaga penjualan) yang dinilai sukses adalah yang dapat menunjukkan perilaku yang lebih etis daripada karyawan tidak sukses.

Penelitian yang dilakukan oleh Schwepker and Good (2011) telah mengeksplorasi dampak pertimbangan moral terhadap kinerja penjualan dan keterlibatan tenaga penjualan yang berorientasi pada pelanggan. Dengan menggunakan sampel 345 tenaga penjualan B2B, mereka menemukan bahwa pertimbangan moral berpengaruh pada perilaku kinerja dan penjualan yang berorientasi pelanggan, serta tidak berpengaruh pada hasil kinerja.

\section{Moral Kognitif dan Kinerja Tenaga Penjualan}

Beberapa penelitian ( seperti Goolsby dan Hunt, 1992; Latif, 2000; Schwepker, 1999; Selvarajan dan Cloninger, 2009; Schwepker dan Good, 2011) menguji pertimbangan moral (yaitu keputusan untuk berperilaku benar atau salah), nilai-nilai moral (yaitu, keyakinan individu tentang nilai dan tindakan yang benar atau salah), pengembangan kognitif moral (yaitu, pengembangan penalaran moral), dalam pengambilan keputusan kinerja pemasaran. Pertimbangan moral merupakan inti yang etis dalam model pengambilan keputusan dalam bidang pemasaran seperti kinerja.

Hal ini didukung oleh Schwepker dan Ingram (1996) mengatakan bahwa antara pertimbangan moral dan kinerja tenaga penjualan mempunyai hubungan kuat dan positif antara keduanya. Hansen dan Riggle (2009), perilaku etis tenaga penjualan mempunyai penilaian konsekuensi moral yang mengarah pada kinerja yang lebih besar. Beliau menemukan bahwa terdapat korelasi positif antara perilaku etis tenaga penjualan dan membangun kepercayaan pelanggan. Pernyataan ini diperkuat oleh peneliti yang mengatakan bahwa pembeli cenderung membeli dari penjual yang mereka percayai dan mempunyai kejujuran (Bingham dan Dion, 1991).

Penelitian tentang ukuran laporan diri tentang kinerja dikembangkan oleh Behrman dan Perreault (1982). Dengan menggunakan sample tenaga penjualan industri mereka menemukan hubungan yang signifikan antara penalaran moral dengan tiga dimesi kinerja (keberhasilan pencapaian kuantitas dan mutu sasaran penjualan, pengembangan dan penggunaan pengetahuan terkini atau presentasi penjualan, mengendalikan biaya yang tidak perlu).

Schwepker dan Good (2011) meneliti hubungan antara pertimbangan moral, penjualan yang berorientasi pelanggan, kinerja hasil dan kinerja keperilakuan. Temuan mereka bahwa pertimbangan moral dan penjualan yang berorientasi pelanggan mempunyai hubungan positif. Namun, pertimbangan moral tidak secara signifikan berhubungan dengan kinerja hasil akan tetapi secara signifikan berhubungan dengan kinerja keperilakuan. Sedangkan penjualan yang berorientasi pelanggan berhubungan secara signifikan dengan kinerja hasil dan kinerja perilaku. Hal ini menunjukkan bahwa tenaga penjualan yang membuat keputusan lebih etis mereka lebih berorientasi pada pelanggan dan memiliki tingkat yang lebih tinggi pada kinerja keperilakuan.

Berdasarkan diskusi diatas hipotesis yang dikemukakan:

$\mathrm{H}_{1}$ : Moral kognitif berpengaruh positif pada kinerja keperilakuan tenaga penjualan.

$\mathrm{H} 2$ : Moral kognitif berpengaruh positif pada kinerja hasil tenaga penjualan

\section{Kinerja Keperilakuan dan Kinerja Hasil Tenaga Penjualan}




\section{Ribhan \\ Nasrullah Yusuf}

Kinerja keperilakuan tenaga penjualan merupakan dimensi penting yang berkaitan langsung dengan kinerja hasil penjualan. Tenaga penjualan biasanya menghabiskan banyak waktu pada kegiatan-kegiatan yang berkaitan langsung dengan hasil penjualan (Cravens et al., 1993). Contoh kegiatan ini seperti persentasi penjualan, meyakinkan pelanggan dan memahami pelanggan. Walaupun tenaga penjualan memiliki kegiatan-kegiatan dalam proses menjual, namun hasil penjualan mereka merupakan hasil langsung yang terkait dengan kemampuan dan kinerja penjualan secara keseluruhan.

Perilaku kinerja mengacu pada kegiatan dan strategi tenaga penjualan dalam melaksanakan proses penjualan, sedangkan hasil kinerja merupakan hasil kuantitatif dari vasaha tenaga penjualan (Baldauf et al., 2005 dalam Miao dan Evans, 2007). Beberapa penelitian menunjukkan terdapat hubungan kausal positif antara kinerja keperilakuan dan kinerja hasil penjualan (Cravens et al., 1993; Jaworski dan Kohli, 1991). Berdasarkan diskusi diatas hipotesis penelitian ini:

H3: Kinerja keperilakuan berpengaruh positif pada kinerja hasil tenaga penjualan.

\section{METODE PENELITIAN}

Penelitian ini menguji pengaruh moral kognitif pada kinerja keperilakuan dan kinerja hasil organisasi dengan menggunakan metode survey. Sampel yang digunakan adalah tenaga penjualan pada beberapa kelompok industri. Metode pengumpulan data dengan metode survey, pengambilan sampel yang dilakukan adalah dengan menggunakan metode purposive sampling artinya hanya tenaga penjual (salesperson) karyawan tetap yang bekerja paling lama satu tahun dan mempunyai target perorangan. Jumah sampel sebanyak 150 tenaga penjual. Obyek yang akan diteliti adalah tenaga penjual pada beberapa kelompok industri (industri obat-obatan, asuransi, perdagangan, otomobil) yang berada di Provinsi Lampung. Alat analisis yang digunakan dalam penelitian ini adalah regresi.

\section{Pengukuran Variabel Penelitian}

Pertimbangan Moral. Pertimbangan moral diukur dengan skala multidimensi etika dimaksudkan untuk mengukur berbagai kerangka nilai-nilai moral individu (Reidenbach et al., 1991 dalam Schwepker dan good, 2011). Responden memberi tanggapan terhadap tiga skenario yang berbeda dengan menanggapi delapan pernyataan, skala 7 (tujuh) poin semantik diferensial bipolar kata sifat (misalnya, adil / tidak adil; benar secara moral / moral tidak kanan). Penyataan mencakup tiga dimensi etis: (1) ekuitas moral; (2) dimensi relativistik, dan; (3) dimensi contractualism. Dimensi ini terdiri dari tiga filosofi etika yang berbeda, termasuk keadilan, relativisme dan deontologi.

Kinerja Tenaga Penjualan, diukur dari instrument yang dikembangkan oleh Schwepker dan good (2011) dan Sujan et al (1994) kinerja hasil dan kinerja perilaku yang terdiri dari tujuh item yang digunakan untuk menilai sejauh mana tenaga penjualan mencapai target penjualan dan empat item untuk kinerja keperilakuan. Tiap pertanyaan dengan menggunakan skala likert 7 poit.

Uji validitas dilakukan dengan mengggunakan analisis faktor. Pengujian reliabilitas ditunjukkan oleh koefisien cronbach alpha. Untuk menguji pengaruh variabel independen terhadap variabel dependen digunakan model regresi sederhana.

\section{HASIL DAN PEMBAHASAN}

Dengan menggunakan analisis faktor, ketiga konstruk diuji validitasnya. Validitas variabel moral kognitif mempunyai faktor loading 0,698 dan koefisien reliabilitas konstruk moral kognitif Cronbach's alpha 0,895 dengan jumlah item pertanyaan akhir 17 item pertanyaan pertimbangan moral tenaga penjual. 
Variabel kinerja terbagi menjadi dua yaitu kinerja hasil (ukuran kuantitatif) dan kinerja perilaku (ukuran perilaku). Kinerja hasil mempunyai nilai factor loading adalah 0,778 dan nilai koefisien Cronbach's alpha 0,848 untuk 6 item pertanyaan. Nilai faktor loading konstru kinerja perilaku sebesar 0,748 (item pertanyaan) dan nilai koefisien Cronbach's alpha 0,855 untuk 2 item pertanyaan.

Koefisien Cronbach's alpha dihitung untuk mengestimasi reliabilitas setiap skala (variabel diamati atau indikator). Nilai croncbach's alpha if item deleted dibandingkan dengan nilai croncbach's alpha digunakan untuk menghilangkan item pertanyaan sehingga diperoleh croncbach's alpha yang lebih besar.

Table 1 Koefisien Reliabilitas Croncbach's Alpha Konstruk

\begin{tabular}{|c|c|c|c|}
\hline Konstruk & $\begin{array}{c}\text { Banyaknya Item pertanyaan } \\
\text { Dalam Konstruk }\end{array}$ & $\begin{array}{c}\text { Sisa Item } \\
\text { pertanyaan }\end{array}$ & $\begin{array}{c}\text { croncbach's } \\
\text { alpha }\end{array}$ \\
\hline Moral Kognitif & 27 items & 17 items & 0,895 \\
\hline Kinerja Hasil & 7 items & 6 items & 0,848 \\
\hline Kinerja Perilaku & 4 items & 2 items & 0,855 \\
\hline
\end{tabular}

Dengan menggunakan regresi sederhana diperoleh hasil bahwa dua dari tiga hipotesis penelitian mendapat dukungan dan satu hipotesis tidak mendapat dukungan:

Tabel 2 Hasil Regresi Variabel Penelitian

\begin{tabular}{|c|l|c|c|l|}
\hline Hipotesis & $\begin{array}{c}\text { Pengaruh Variabel } \\
\text { Dependen dan Independen }\end{array}$ & $\begin{array}{c}\text { Beta Standardized } \\
\text { coefficient }\end{array}$ & Signifikansi & Kesimpulan \\
\hline Hipotesis 1 & $\begin{array}{l}\text { Moral Kognitif } \rightarrow \text { Kinerja } \\
\text { Perilaku }\end{array}$ & $-0,296$ & 0,000 & Didukung \\
\hline Hipotesis 2 & Moral Kognitif $\rightarrow$ Kinerja Hasil & $-0,122$ & 0,148 & $\begin{array}{l}\text { Tidak } \\
\text { didukung }\end{array}$ \\
\hline Hipotesis 3 & $\begin{array}{l}\text { Kinerja Keprilakuan } \rightarrow \text { Kinerja } \\
\text { Hasil }\end{array}$ & 0,217 & 0,009 & Didukung \\
\hline
\end{tabular}

Hipotesis $\mathrm{H} 1$ yang menyatakan bahwa moral kognitif berpengaruh pada kinerja keperilakuan tenaga penjual, berpengaruh singnifikan $(b=-0,296$; sig 0,000$)$ didukung. Temuan menunjukkan pengaruh moral kognitif terhadap kinerja keperilakuan terjadi secara negatif. Yang menarik dalam penelitian ini, berbeda dengan penelitian terdahulu yang mengatakan bahwa moral kognitif berdampak positif pada kinerja keperilakuan dan kinerja hasil. Hal ini mengindikasikan bahwa kinerja keperilakuan karyawan dipengaruhi oleh pertimbangan moral yang rendah. Perilaku kerja yang baik pada konsumen seringkali ditentukan oleh moral-moral yang tidak etis tenaga penjualan seperti mengeluh kepada konsumen, membohongi konsumen dan tidak bertanggungjawab. Hipotesis 2 tidak didukung, yang mengemukakan bahwa pertimbangan moral berpengaruh pada kinerja hasil dalam penelitian ini tidak signifikan ( $b=-0,122$; sig 0,148$)$. Kinerja hasil seperti pencapaian target dan market share tenaga penjualan dipengaruhi oleh pertimbangan moral tenaga penjualan yang rendah dan tidak signifikan. Hipotesis ini mendapat dukungan dari Schwepker dan Good (2011) pertimbangan moral berdampak tidak signifikan dengan kinerja hasil tetapi berhubungan signifikan dengan kinerja keperilakuan.

Tenaga penjualan yang melakukan pertimbangan moral yang lebih etis akan lebih memungkinkan untuk memiliki kinerja keperilakuaan yang lebih tinggi dibandingkan dengan kinerja hasil. Artinya tenaga penjual dengan nilai-nilai moral yang lebih tinggi dan mereka yang menggunakan tingkat penalaran moral kognitif yang lebih tinggi, mereka cenderung tidak berpartisipasi dalam perilaku yang tidak etis. 


\section{Ribhan Nasrullah Yusuf}

H3 yang menyatakan bahwa kinerja keperilakuan berpengaruh positif pada kinerja hasil mendapat dukungan ( $\mathrm{b}=0,217$; sig 0,009$)$. Temuan ini mendukung penelitian terdahulu (Jaworski dan Kohli, 1991; Cravens et al., 1993; Baldauf et al., 2005; Miao dan Evans, 2007).

\section{Pembahasan}

Pertimbangan moral atau moral kognitif diperlukan dalam model pengambilan keputusan yang etis dalam bidang pemasaran dan manajemen karena perkembangan moral kognitif adalah elemen penting dalam tahap penilaian keputusan-keputusan yang etis. Bila tenaga penjualan membuat keputusan lebih etis maka mereka akan memiliki tingkat yang lebih tinggi pada kinerjanya. Hal ini didukung oleh Weeks dan Nantel (1992) yang mengatakan bahwa tenaga penjualan yang memahami kebijakan etika perusahaan akan menunjukkan kinerja pekerjaan yang lebih tinggi. Perilaku etis tenaga penjualan mempunyai penilaian konsekuensi moral yang mengarah pada kinerja yang lebih besar.

Pengembangan moral kognitif dikembangkan secara konseptual dan diuji secara empiris oleh Kohlberg (1984 dalam Goolsby dan Hunt 1992) sebagai cara untuk menggambarkan dan menjelaskan proses pembuatan keputusan etis dan etika individu. Dalam bidang pemasaran, proses pembuatan keputusan etis diarahkan untuk meningkatkan kinerja individu dalam menciptakan kepuasan pelanggan eksternal (konsumen). Karakteristik unik pemasaran, khususnya peran pemasaran yang makin luas dan komplek, adalah kondusif bagi perilaku tidak etis. Dengan demikian, persoalan etika muncul dari fakta bahwa pemasaran pada dasarnya melibatkan penyatuan kebutuhan dari publik yang beragam. Tindakan etis dan tidak etis dari praktisi pemasaran (seperti tenaga penjualan), akan lebih dirasakan oleh konsumen eksternal.

Miles (1980 dalam Goolsby dan Hunt 1992) menyatakan bahwa karakteristik unik pemasaran, khususnya peran pemasaran yang makin luas dan komplek, adalah kondusif bagi perilaku tidak etis. Dengan demikian, persoalan etika muncul dari fakta bahwa pemasaran pada dasarnya melibatkan penyatuan kebutuhan dari publik yang beragam. Pendapat lain menyatakan bahwa tindakan etis dan tidak etis dari praktisi pemasaran (seperti tenaga penjualan), akan lebih dirasakan oleh konsumen eksternal dibandingkan dengan tindakan di bidang lain, sehingga lebih rentan terhadap kritikan perilaku tidak etis (Ferrell dan Gresham 1985).

Penelitian kami menemukan bahwa perkembangan moral tenaga penjualan pada beberapa kelompok industri (industri obat-obatan, asuransi, perdagangan, otomobil) yang berada di Provinsi Lampung masih dalam tahap pra-konvensional (Kohlberg, 1984 dalam Goolsby dan Hunt 1992). Seseorang yang berada dalam tingkat pra-konvensional menilai moralitas dari suatu tindakan berdasarkan konsekuensinya langsung. Pada tingkat ini, seseorang tidak memperlihatkan internalisasi nilai-nilai moral- penalaran moral dikendalikan oleh imbalan (hadiah) dan hukuman eksternal. Dengan kata lain aturan dikontrol oleh orang lain (eksternal) dan tingkah laku yang baik akan mendapat hadiah dan tingkah laku yang buruk mendapatkan hukuman.

Tingkat pre-konvensional pengembangan moral kognitif ditandai dengan keputusan individu berdasarkan pada keprihatinan eksklusif individu untuk diri nya sendiri atau kepentingan pribadi tanpa memperhatikan dampak dari tindakannya pada pada orang lain. Pada tingkat ini, individu sering bertindak dalam rangka untuk menghindari hukuman. Bahkan ketika individu tertarik pada kesejahteraan lainnya, motif ini untuk mencapai kepentingan pribadi jangka panjang. Pada tingkat ini mereka bereaksi terhadap masalah etis dari sudut pandang egois, mengevaluasi pilihan moral terutama dalam hal konsekuensi pribadi, kebutuhan, dan pertukaran keuntungan. Tindakan perbaikan mereka mengarah pada penghargaan pribadi dan memungkinkan meraka atau seseorang untuk menghindari hukuman. Individu pada tingkat satu lebih rentan terhadap kepentingan diri sendiri (tingkat satu) dan tekanan perilaku tim (tingkat dua). Individu ini adalah orang yang paling mungkin 
dipengaruhi oleh perilaku pengawas atau atasan, terlepas dari apakah perilaku tersebut etis atau tidak etis.

Sebagai tenaga penjual yang bergerak ke arah pelaksanaan strategi yang dirancang untuk mendorong dan saling mendukung hubungan jangka panjang dengan pelanggan (Weber 1992), mereka dituntut untuk memulai, menetapkan, dan memelihara hubungan yang abadi. Sebuah pengembangan hubungan jangka panjang menunjukkan pentingnya penempatan perilaku etis (perilaku yang bermoral) yang tinggi. Moral Kognitif dan etika memberikan bimbingan kemampuan perubahan perilaku dalam mempertahankan pertukaran relasional yang lebih fleksibel sehingga mencapai kinerja organisasi secara keseluruhan.

Hasil penelitian ini menemukan bahwa moral kognitif atau pertimbangan moral akan mengarahkan perilaku tenaga penjualan pada keptusan yang bertanggung jawab, namun tidak mngarahkan pada pencapaian kinerja hasil pada tenaga penjualan. Hal ini berarti bahwa pencapaian hasil atau kinerja hasil tenaga penjualan tidak dipengarauhi oleh pertimbangan-pertimbangan etika dalam pengambilan keputusan seorang tenaga penjualan. Hal yang menarik dalama penelitian ini kinerja keprilakuan tenaga penjualan berdampak positif signifikan pada kinerja hasil. Temuan ini menggambarkan bahwa perilaku yang bertanggungjawab dan baik akan mengarahkan hasil yang baik pula bagi tenaga penjualan.

Kesimpulan penelitian ini, untuk memperoleh kinerja hasil seorang individu yang baik dan bertanggungjawab, maka harus meningkatkan atau memperbaiki perilaku dalam pengambilan keputusan yang didasarkan pada tingkatan moral kognitif tenaga penjualan. Kinerja hasil tenaga penjualan meningkat ketika perilaku kerja tenaga penjualan lebih baik dan bertanggungjawab. Temuan kami menggambarkan bahwa pertimbangan moral dalam pengambilan keputusan dari tenaga penjualan kurang mempengaruhi kinerja tenaga penjualan. Untuk itu kami menyarankan bagi para professional pemasaran dan organisasi-organisasi pemasaran lainnya mempertimbangkan moral-moral tenag penjualan dengan melakukakan pelatihan-pelatihan, peningkatan pengetahuan karyawan terhadap pentinya membangun dan membina hubungan jangka panjang pada konsumen.

Penelitian kami hanya menggunakan rersponden pada beberapa kelompok industri di ruang lingkup yang kecil. Oleh karenanya temuan kami masih kurang sempurna. Untuk penelitian selanjutnya kami menyarankan menggunakan sampel yang lebih luas pada kelompok beberapa industri dan dengan wilayah yang lebih luar sehingga tingkat validitas eksternal nya lebih baik.

Untuk penelitian-penelitian selanjunnya direkomendasikan menggunakan metode-metode lain seperti misalnya misalnya structural equation models (SEM) dengan model penelitian yang lebih kompleks dan metode eksperimen baik eksperimen lapangan ataupun laboraturium.

Akhirnya, penelitian mendatang diharapkan dapat mengembangkan variabel-variabel lain dalam hubungannya dengan moral kognitif dan kinerja keseluruhan organisasi (kinerja keperilakuan dan kinerja hasil).

\section{DAFTAR REFERENSI}

Ahmed, P.K., Rafiq, M., and Saad, N.M. 2003. Internal marketing and the mediating role of organizational competencies. European Journal of Marketing, 37, 9, 1221-1241.

Anderson, E. and R. L. Oliver. 1987. Perspectives on Behavior-Based Versus Outcome-Based Salesforce Control Systems. Journal of Marketing. Vol 51 (October), 76-88. 


\section{Ribhan}

\section{Nasrullah Yusuf}

Ambrose, Maureen L., Arnaud, Anke and Schminke, Marshall. 2008. Individual Moral Development and Ethical Climate: The Influence of Person-Organization Fit on Job Attitudes. Journal of Business Ethics 77:323-333 _ Springer 2007

Austin, J. T. and Villanova, P. 1992. The criterion problem: 1917- 1992. Journal of Applied Psychology, Vol 77, 836-874.

Bagozzi, R.P. 1981. Attitudes, intentions, and behavior: a test of some key hypotheses. Journal of Personality and Social Psychology, 41, 4, 607-627.

Bingham, F. G. and P. Dion. 1991. Are Buyers Misled by Their Perceptions of Salespeople: An Empirical Investigation. The Journal of Marketing Management, Vol.1, 43-49.

Bommer, M., Cratto, C., Gravander J., Tuttle M. 1987. A Behavioral Model of Ethical and Unethical Decision Making. Journal of Business Ethics, Vol 6 No.4, 265-280.

Chi, HK., Yeh, HR., Chiou, CY. 2008. The Mediating Effects of Internal Marketing on Transformational Leadership and Job Performance of Insurance Salespersons in Taiwan. The Business Review, Cambridge; Vol. 11 ; Num. 1 ; December.

Chang, CS., Chang HH. 2007. Effects of Internal Marketing on Nurse Job satisfaction and Organizational Commitment: Example of Medical Centers in Southern Taiwan. Journal of Nursing Research Vol.15 No.4. p 265-273.

Cooper, R.D., dan Emory,W.C. 1995. Business Research Methods (5th edition). London: Richard D.Irwin, Inc.

Cravens, DW., Ingram TN., LaForge RW., Clifford E., 1993. Behavior-Based and OutcomeBased Salesforce Control Systems. The Journal of Marketing, Vol. 57, No. 4 (Oct), 47-59

Dubinsky, A. J., Loken B., Jolson M. A., Michaels R. E., Kotabe M., Lim, C. U. 1992. Ethical Perceptions of Field Sales Personnel: An Empirical Assessment. Journal of Personal Selling \& Sales Management 12(Fall), 9-21

Donnell, S. M., Hall J. 1980. Men and Women as Managers: A Significant Case of No Significant Difference. Organizational Dynamics, Spring: 60-77.

Dubno, P. 1985. Attitudes Toward Women Executives: A Longitudinal Approach. Academy of Management Journal, 28, 235-239.

Dubno, P., Costas J., Cannon H., Wankel C., Emin H. 1979. An Empirically Keyed Scale for Measuring Managerial Attitudes Toward Female Executives. Psychology of Women Quarterly, 3, 357-364.

Dubinsky, A. J. B., Loken, B. 1989. Analyzing Ethical Decision Making in Marketing. Journal of Business Research, Vol 19, 83-107.

Ferrell, O. C., Gresham G. 1985. A Contingency Framework for Understanding Ethical Decision Making, Journal of Marketing, 49, 87-96.

Ferrell, O. C., Gresham L. G., Fraedrich J. 1989. A Synthesis of Ethical Decision Models for Marketing', Journal of Macromarketing, 9(Fall), 55-64.

Fishbein, M., Ajzen I. 1975. Belief, Attitude, Intention, and Behavior: An Introduction to Theory and Research. Addison-Wesley, Reading, Mass.

Gilbert, J. 2003. A Matter of Trust. Sales \& Marketing Management, 155, 30-35.

Goolsby, J. R. Shelby D. H.1992. Cognitive Moral Development and Marketing. Journal of Marketing, 56, 1, 55

Gomez-Mejia, L.R., Balkin, D.B., Cardy, R.L. 2007. Managing Human Resources. Upper Saddle River, New York: Pearson Education International.

Gundlach, G. T., Murphy P. E. 1993. Ethical and Legal Foundations of Relational Marketing Exchanges. Journal of Marketing, Vol 57, 35-46.

Ha, NC., Bakar, RA, Jaafar, SIS. 2007. Internal Marketing Issues in Service Organizations in Malaysia. Faculty of Business dan Accountancy. University of Malaya, Malaysia

Hair, J.F., Black, W.C., Babin, B.J., Anderson, R.E., Tatham, R.L. 2006. Multivariate data analysis, New Jersey: Prentice-Hall International, Inc.

Hansen, J. D., Riggle R. J. 2009. Ethical Salesperson Behavior in Sales Relationships. Journal of Personal Selling and Sales Management, Vol.29 (Spring), 151-166.

Heneman, H.G. Judge, T.A. 2003. Staffing Organizations, McGraw Hill, Middleton, 76-85.

Hunt, SD., Hansen, JM. 2007. Understanding Ethical Diversity in Organizations. Organizational Dynamics, Vol. 36, No. 2, 202-216.

Hunt,S.D. and S.J. Vitell. 2006. The General Theory of Marketing Ethics: A Revision and Three Questions, Journal of Macromarketing, Vol. 26 No. 2, December, 1-11. 


\section{Jurnal Manajemen Teori dan Terapan \\ Tahun 6. No. 1, April 2013}

Hwang, IS., Chi, DJ. 2005. Relationships among Internal Marketing, Employee Job Satisfaction and International Hotel Performance: An Empirical Study. International Journal of Management, Vol. 22 No. 2, 285

Jaramillo F., Jay PM., Greg WM, 2005. A meta-analysis of the relationship between organizational commitment and salesperson job performance: 25 years of research. Journal of Business Research 58: 705- 714

Jaworski, B.J., Kohli A.K. 1991. "Supervisory Feedback: Alternative Types and Their Impact on Salespeople's Performance and Satisfaction," Journal of Marketing Research, Vol. 28, No. 2, 190-201

Jenkins, M. Griffith R. 2004. Using Personality Construct To Predict Performance: Narrow or Broad Bandwidth. Journal of Business and Psychology, Vol. 19, No. 2, Winter .

Jones, T. M. 1991, Ethical Decision Making by Individuals in Organizations: An Issue-Contingent Model, Academy of Management Review, 16 (April), 366-395.

Kerlinger, N. F. (Penerjemah: Simatupang Ladung R). 1998. Asas-asas Penelitian Behavioral (edisi Indonesia). Gadjah Mada University Press.

Kohlberg, L. 1969, Stage and Sequence: The Cognitive-Developmental Approach to Socialization, in D. A.Goslin (ed.), Handbook of Socialization Theory and Research, Chicago: Rand McNally, 347-480.

Lagace, R. R., Dahlstrom R., Gassenheimer J. B. 1991. The Relevance of Ethical Salesperson Behavior on Relationship Quality: The Pharmaceutical Industry. Journal of Personal Selling \& Sales Management, Vol 11 (Fall), 39-47.

Latif, D. A. 2000. The Link Between Moral Reasoning Scores, Social Desirability, and Patient Care Performance Scores: Empirical Evidence from the Retail Pharmacy. Journal of Business Ethics, Vol.25, 255-269.

Miao,C.F., Evans K.R. 2007.The impact of salesperson motivation on role perceptions and job performance - a cognitive and afective perspective," Journal of Personal Selling \& Sales Management, Vol. 27 No. 1 (winter), 89-101.

Motowidlo, S. J. 2003. Job performance, In W. C. Borman, D. R. Ilgen, and R. J. Klimonski. Handbook of psychology (industrial/organizational psychology (12th eds), New York: Wiley. 39-53.

Motowidlo, S. J., Van Scotter, J. R. 1994. Evidence that task performance should be distinguished from contextual performance. Journal of Applied Psychology. Vol.79, 475-480.

Oakes, D. W., Ferris G.R., Martocchio J.J., Buckley M.R., Broach D. 2001. Cognitive Ability And Personality Predictors Of Training Program Skill Acquisition And Job Performance, Journal of Business and Psychology Vol. 15, No. 4, Summer

Park, J.E., Deitz G.D. 2006. The effect of working relationship quality on salesperson performance and job satisfaction: Adaptive selling behavior in Korean automobile sales representatives, Journal of Business Research, Vol. 59, $204-213$

Pincus, J.D. 1986. Communication satisfaction, job satisfaction, and job performance. Human Communication Research, Vol. 12, No. 3, 395-419.

Rest, J. R. 1986. Moral Development: Advances in Research and Theory. New York: Praeger Publishers.

Reidenbach, R. E., Robin D. P., Dawson L. 1991. An Application and Extension of a Multidimensional Ethics Scale to Selected Marketing Practices. Journal of the Academy of Marketing Science, Vol.19(Spring), 83-92.

Riggio, R. E., Taylor S.J. 2000. Personality And Communication Skill As Predictors Of Hospice Nurse Performance. Journal of Business and Psychology, Vol. 15, No. 2, Winter.

Roman, S., Ruiz S. 2005. Relationship Outcomes of Perceived Ethical Sales Behavior. Journal of Business Research, Vol 58(April), 439-445.

Selvarajan, R., Peggy AC. 2009. The influence of job performance outcomes on ethical assessments. Personnel Review, Vol. 38 No. 4, 398-412

Schwepker, C. H. Jr ., David JG. 2011 . Moral Judgment and its Impact on Business-to-Business Sales Performance and Customer Relationships . Journal of Business Ethics, 98, 609-625 


\section{Ribhan}

Nasrullah Yusuf

Schwepker, C.H.Jr., Ingram, T.N. 1996. Improving Sales Performance through Ethics: The Relationship between Salesperson Moral Judgment and Job Performance. Journal of Business Ethics, Vol. 15, No. 11, 1151-1160

Schwepker, C.H. Jr. 1999. Research note: The relationship between ethical conflict, organizational commitment and Turnover Intentions in the Salesforce. The Journal of Personal Selling dan Sales Management, Winter Vol.19, No.1, 43

Sekaran, U. 2000. Research Methods for Business. 4th Edition, New York: John Wiley dan Son, Inc.

Sojka, J. Z., Deeter-Schmelz, D.R. 2008. Need for Cognition and Affective Orientation as Predictors of Sales Performance: An Investigation of Main and Interaction Effects. Journal of Business Psychology, Vol.22, 179-190.

Sujan, H., Barton A. W, Nirmalya. K. 1994. Learning Orientation, Working Smart, and Effective Selling. The Journal of Marketing, Vol. 58, No. 3, 39-52

Trevino, L. K. 1986. Ethical Decision Making in Organizations: A Person-Situation Interactionist Model. Academy of Management Review, 11 (July), 601-617.

Trevino, L., Butterfield, K., McCabe D. 1998. The ethical context in organizations: Influences on employee attitude and behaviors. Business Ethics Quarterly, Vol 8 No 3, 447-476.

Vitell, S. J., Festervand T. A. 1987. Business Ethics: Conflicts, Practices and Beliefs of Industrial Executives. Journal of Business Ethics, 6(2), 111-122.

Valentine, S. 2009. Ethical Training, Ethical Context,and Sales and Marketing Professionals' Satisfaction with Supervisors and Coworkers, Journal of Personal Selling \& Sales Management, 29 (Summer), 227-242.

Varela, O.E., Landis, R.S. 2010. A General Structure of Job Performance: Evidence from Two Studies. Journal of Business and Psychology, Vol.25, 625-638

Wall, T.D., Michie, J., Patterson, M., Wood, S. J., Sheehan, M., Clegg, C. W., West, M. 2004. On the validity of subjective measures of company performance. Personnel Psychology, Vol. 57, No. 2, 95-118.

Webb, A. P., Badaracco J. L. 1995. Business Ethics: A View from the Trenches. California Management Review, 37(2), 8-28

Weeks, W. A., Nantel J. 1992. Corporate Codes of Ethics and Sales Force Behavior: A Case Study, Journal of Business Ethics, Vol.11, 753-760

Weber, J. 1992. Scenarios in Business Ethics Research: Review, Critical Assessment, and Recommendations. Business Ethics Quarterly, Vol 2, 138-159.

Wiedower, K.A. 2001. A shared vision: The relationship of management communication and contingent reinforcement of the corporate vision with job performance, organizational commitment, and intent to leave. Unpublished Doctoral Dissertation, Alliant International University, California.

Wimbush, J.C. 1999. The Effect of Cognitive Moral Development and Supervisory Influence on Subordinates' Ethical Behavior. Journal of Business Ethics, 18, 383-395. 